\title{
A Short Review on E-Waste: Challenges and Management in India
}

\author{
Mahima Chaurasia ${ }^{1}$, Sanjeev Kumar Srivastava ${ }^{2}$, Ranjan Singh ${ }^{3 *}$, \\ Ranjana Sikarwar ${ }^{4}$ and Rajeeva Gaur $^{3}$
}

${ }^{1}$ Department of Engineering and Technology, ${ }^{2}$ Department of Environmental Sciences, ${ }^{3}$ Department of Microbiology, Dr. Ram Manohar Lohia Avadh University, Ayodhya, Uttar Pradesh, India

${ }^{4}$ Department of Computer Sciences, Amity University, Gwalior Campus, Gwalior, Madhya Pradesh, India

*Corresponding author

Keywords

E-Waste,

Recycling, Health Hazards, Metallic Contamination, EWaste Management

Article Info

Accepted:

12 April 2021

Available Online: 10 May 2021
In India, the quantity of "E-Waste" or Electronic Waste has now become a major problem. Electronic wastes (E-Wastes) typically include discarded computer monitors, motherboards, mobile phones and charges, compact discs, headphones, television sets, A.C. and refrigerators. Only 20 percent of global E-Waste is recycled. In India most of the waste electronic items are stored at households as people do not know how to discard them. This ever-increasing waste is very complex in nature and is also a rich source of metals. A large number of workers are involved in crude dismantling of these electronic items for their livelihood and their life is at risk. The review outlines the problems arising due to increasing burden of E-Waste in India and its management.

\section{Introduction}

In India, the quantity of "E-Waste" or Electronic Waste has now become a major problem. Disposal of E-Waste is an emerging global environmental and public health issue, as this waste, has become the most rapidly growing segment of the formal municipal waste stream in the world (Dahl, 2002). Electronic Waste (E-Waste) typically includes discarded computer monitors, motherboards, mobile phones and chargers, compact discs, headphones, television sets, A.C. and Refrigerators. According to the Global EWaste Monitor 2017, India generates about 2 Million Tonnes (MT) of E-Waste annually and ranks fifth among E-Waste producing countries after USA, China, Japan and Germany. In 2016-2017, India treated only 0.036 MT of its E-Waste. About $95 \%$ of India 
E-Waste is recycled in the informal sector and in a crude manner. A report on E-Waste presented by the United Nation (UN) in World Economic Forum on January 24, 2019 points out that the waste stream reached 48.5 MT and the figure is expected to double if nothing is done.

Only $20 \%$ of global E-Waste is recycled. The $\mathrm{UN}$ report indicates that due to poor extraction techniques the total recovery rate of Cobalt (the metal which is in great demand for laptop, smart phone and electric car batteries) from EWaste is only $30 \%$.

The report cites that one recycler in China already produces more cobalt (by recycling) than what the country mines in one year. Recycled metals are also 2 to 10 times more energy-efficient than metals smelted from virgin ore. The report suggests that lowering the amount of electronic entering the waste stream and improving end of life handling are essential for building a more circular economy, where waste is reduced, resources are conserved and are fed back into the supply chain for new products.

E-Waste or Waste Electrical and Electronic Equipment (WEEE) are loosely discarded, surplus, obsolete, broken, electrical or electronic devices. In India most of the waste electronic items are stored at households as people do not know how to discard them. This ever-increasing waste is very complex in nature and is also rich source of metals which can be recovered and brought back into the production cycle. E-Waste trade and recycling alliances provide employment to many groups of people in India (Baud et al., 2001). On a positive note, media reports highlighted that the 2021 Tokyo Olympics Medals will be made of 50,000 tons of E-Waste. The organizing committee will make all the medals from old smart phones, laptops and other gadgets. By November 2018, organizers had collected 47,488 tons of devices, from which nearly 8 tons of Gold, Silver and Bronze will be extracted to make 5,000 medals.

Laws to manage E-Waste have been enforced in India since 2011, mandating that only authorized dismantlers and recyclers collect EWaste. E-Waste Management rules was enacted on October 1, 2017. Over 21 products were included under the purview of the rule. The rule also extended its purview to components or consumables or parts or spares of Electrical and Electronic Equipment (EEE), along with their products. The rule has strengthened the Extended Producer Responsibility (EPR), which is the global best practice to ensure the take back of the old products. A new arrangement called Producer Responsibility Organization (PRO) has been introduced to strengthen EPR further. The producers have to meet targets, which should be $20 \%$ of the waste generated by their sales. This will increase by $10 \%$ annually for the next five years. The law also says that the responsibility of producers is not confined to waste collection but also to ensure that the waste reaches the authorized recycler. Despite new rules that have come into place to safely process this hazardous material, close to $80 \%$ of E-Waste continues to be broken down at the cost of polluting the soil water and air at the large.

E-waste is growing at a Compound Annual Growth Rate (CAGR) of about $30 \%$ in the country. One of the associations dealing with E-Waste Management in India estimated that E-Waste generation was 1.8 MT per annum in 2016 which grew to 5.2 MT in 2020. India now has 178 registered E-Waste recyclers, accredited by the state governments to process E-Waste. But many of India E-Waste recyclers are not recycling waste at all. While some are storing it in hazardous conditions, other don't even have the capacity to handle such waste. Around 25,000 workers including 
children, are involved in crude dismantling units in New Delhi alone where 10,000-20,000 tons of E-Waste is handled every year by bare hands. Improper dismantling and process of EWaste render it perilous to human health and our ecosystem. Therefore, the need of proper E-Waste management has been realized (Pandve, 2007). It is necessary to review the public health risks and strategies to combat this growing menace.

\section{Burden of E-Waste}

In India, solid waste management, with the emergence of E-Waste has become a complicated task. The total waste generated by obsolete or broken down electronic and electrical equipment was estimated to be $1,46,000$ tons for the year $2005,8,00,000$ for 2012, 1.8 MT for 2016 and 5.2 MT in 2020. However, according to the Greenpeace Report India generated 3,80,000 tons of E-Waste in 2007. Only $3 \%$ of this could be recycled. One of the reasons for this is that the India has also become a dumping ground for many developed nations. India is one of the most fastest growing economies of the world and the domestic demand for consumers durables has been skyrocketing. A report states that 50$80 \%$ of E-Waste collected from USA is exported to India, China, Pakistan and to some of the African countries. From 1998 to 2002 there was a $53 \%$ increase in the sales of domestic household appliances both large and small all over the world. A report states that every year 1.38 million computers become obsolete in India accelerating the rate of EWaste generation.

\section{Health Impacts}

Electronic equipment contains many hazardous metallic contaminants such as Lead, Cadmium, Mercury, Chromium, PVC, Beryllium etc. (Table 1). The fraction including Iron, Copper, Aluminum, Gold and other metals in E-Waste is over $60 \%$, while plastic account for about $30 \%$ and the hazardous pollutants comprise only about $2.7 \%$ (Widmer et al., 2004). Lead is one of the most widely used metal in electronic devices for various purposes resulting in a variety of health hazards due to environmental contamination (Jang and Townsend, 2003). Lead enters biological systems via food, water, air and soil. Children are particularly vulnerable to Lead poisoning and their nervous system and blood get affected (Bathurst et al., 1992). It is found that the EWaste recycling activities had contributed to the elevated blood lead levels in children living in China, which is one of the popular destinations of E-Waste. This was due to the fact that the processes and techniques used during the recycling activities were very primitive. Various studies have reported the soaring levels of toxic heavy metals and organic contaminants in sample of dust, soil, river, sediment, surface water and ground water in Guiyu town in China. In the same areas, the residents had a high incidence of skin damage, headaches, vertigo, nausea, chronic gastritis and gastric ulcers (Qiu et al., 2004). Further, it was found that the blood Lead level of children were higher than the level in China, and there were no significant differences between boys and girls (Huo et al., 2007). It was found that E-Waste recycling operations were causing higher levels of polychlorinated dibenzo-para-dioxins and polychlorinated dibenzofurans in the environment as well as on hair, human milk, and placenta in humans (Janet et al., 2007; Wang et al., 2009). In another study from China human scalp hair samples were collected to find out heavy metal exposure to workers from intense E-Waste recycling sites.

Higher concentrations of Lead, Copper, Manganese and Barium metals were found in hair of exposed as compared to the hair in control group (Leung et al., 2007). 
Table.1 Various E-Waste Sources, their Constituents and Health Impacts

\begin{tabular}{|c|c|c|}
\hline E-Waste Sources & Constituents & Effects \\
\hline $\begin{array}{l}\text { Solder in printed circuit } \\
\text { boards, glass panels, } \\
\text { gaskets in computer } \\
\text { monitors }\end{array}$ & Lead & $\begin{array}{l}\text { Damage to Central and } \\
\text { Peripheral nervous } \\
\text { systems, blood system, } \\
\text { kidney Damage. } \\
\checkmark \quad \text { Adverse effects on Brain } \\
\text { Development of Children; } \\
\text { causes damage to the } \\
\text { circulatory system and } \\
\text { kidney. }\end{array}$ \\
\hline $\begin{array}{l}\text { Chip resistors and Semi- } \\
\text { conductors }\end{array}$ & Cadmium & $\begin{array}{ll}\checkmark \quad \text { Toxic irreversible effects } \\
\text { on human health. } \\
\checkmark \quad \text { Accumulates in Kidney } \\
\text { and Liver } \\
\checkmark \quad \text { Causes Neural Damage. }\end{array}$ \\
\hline $\begin{array}{l}\text { Relays and Switches, } \\
\text { Circuit Boards }\end{array}$ & Mercury & $\begin{array}{ll}\checkmark & \text { Chronic damage to the } \\
\text { brain. } \\
\checkmark \quad \begin{array}{l}\text { Respiratory and Skin } \\
\text { disorders due to } \\
\text { bioaccumulation in fishes. }\end{array}\end{array}$ \\
\hline Galvanized Steel Plates & Chromium & $\checkmark \quad$ Causes Bronchitis \\
\hline Cables and Computer & $\mathrm{PVC}$ & $\begin{array}{l}\checkmark \text { Burning produces dioxin } \\
\text { that causes reproductive } \\
\text { and developmental } \\
\text { problems. }\end{array}$ \\
\hline $\begin{array}{l}\text { Electronic Equipment and } \\
\text { Circuit Boards }\end{array}$ & $\begin{array}{l}\text { Brominated flame } \\
\text { Retardants }\end{array}$ & $\begin{array}{l}\checkmark \text { Disrupt endocrine system } \\
\text { functions. }\end{array}$ \\
\hline Front Panels of CRT & $\begin{array}{l}\text { Barium, Phosphorus, Heavy } \\
\text { Metals }\end{array}$ & $\begin{array}{l}\text { Causes Muscle weakness, } \\
\text { damage to Heart, Liver and } \\
\text { Spleen. }\end{array}$ \\
\hline Copper Wires & Copper & $\begin{array}{l}\checkmark \text { Stomach Cramps, Nausea, } \\
\text { Liver damage }\end{array}$ \\
\hline $\begin{array}{c}\text { Nickel- Cadmium } \\
\text { Batteries }\end{array}$ & Nickel & $\begin{array}{l}\text { Allergy of skin to nickel } \\
\text { causes dermatitis while } \\
\text { allergy of lung results in } \\
\text { asthma. }\end{array}$ \\
\hline Lithium-ion Battery & Lithium & $\begin{array}{l}\text { Passes in Mother Milk and } \\
\text { is dangerous for the new } \\
\text { born baby. }\end{array}$ \\
\hline Mother Board & Beryllium & $\begin{array}{ll}\checkmark & \text { Lung Cancer. } \\
\checkmark & \text { Beryllicosis }\end{array}$ \\
\hline
\end{tabular}




\section{Current Status of E-Waste Management}

For the recycling of E-Waste, India heavily depends on the unorganized sector as only a handful of organized E-Waste recycling facilities are available. Over $95 \%$ of the EWaste is treated and processed in the majority of urban slums of the country, where untrained workers carry out the dangerous procedures without personal protective equipment, which are detrimental not only to their health but also to the environment. Recycling and treatment facilities require a high initial investment, particularly those fitted with technologically advanced equipment's and process (Hicks et al., 2005). For the dismantling of one computer piece, these workers only get Rs. 5 to 10 . For such a small amount, workers ruin their lives. Such backyard recyclers do not have waste water treatment facilities, exhaustwaste gas treatment and health protection equipment's (Roman and Puckett, 2002). Therefore, health risk assessments are also required for the analysis of the consequence and of inappropriate management of end-oflife electronic wastes in developing countries (Yanez et al., 2002).

\section{E-Waste Management Initiative in India}

In Environment Protection Act 1986, the "Polluter Pays Principal" is enacted to make the party responsible for producing pollution responsible for paying for the damage done to the natural environment. In international environment law, it is mentioned in Principle 16 of the Rio Declaration on Environment and Development (Kishore, 2007). Polluters pays is also known as Extended Producer Responsibility (EPR). Under the Environment Protection Act 1986, both the Central and the State Governments can enact legislations to safeguard the environment and people from exposure to toxic and hazardous nature of waste. Any violation of the provision of this act or notified rules is liable for punishment
(Kishore, 2010). Each manufacturer of a computer, music system, mobile phone or any other electronic gadget will be "personally" responsible for the final safe disposal of the product when it becomes a piece of E-Waste. Department of Information Technology (DIT), (Ministry of Communication and Information Technology, Government of India), has also published and circulated a comprehensive technical guide on "Environmental Management for Information Technology Industry in India". Demonstration projects have also been set-up by the DIT at the Indian Telephone Industries for the recovery of copper from Printed Circuit Boards.

As an effort to make the users aware of the recycling of E-Waste many electronic companies such as Apple, Dell and HP have started various recycling schemes. Nokia India announced its "Recycling Campaign" for the Indian region. The program encouraged mobile phone users to dispose of their used handsets and accessories, irrespective of the brand, at any of the 1,300 green recycling bins put up across the priority dealers and care centers. The Department of Environment, State Government of Delhi, New Delhi, India, has also decided to involve ragpickers in general waste management in the capital. These ragpickers will be trained to clean waste.

\section{Research on E-Waste Management in India}

Many more environmental epidemiological studies are required to assess the present status of E-Waste Management System in India. Studies are required to assess the E-Waste quantities and exact amplitude of the problem in Indian Cities and to establish relationship with the informal recycling sectors. The valuable data will be generated by these studies that would help in drafting an action plan for E-Waste Management. India should start a surveillance system for disease and 
health consequences in E-Waste. The sustainability of E-Waste Management system has to be ensured by improving the collection and recycling systems. It would be desirable to establish Public-Private Partnership (PPP) in setting up buy-back or drop-off centers. Levying advance recycling fees is another approach to ensure Waste Management Sustainability. To identify best E-Waste Management Technologies across the globe and adopt them successfully can be key to a Sustainable futuristic growth.

The hazardous nature of E-Waste is one of the rapidly growing environmental problems of the world. The ever-increasing amount of EWaste associated with the lack of awareness and appropriate skill is deepening the problem. A large number of workers are involved in crude dismantling of these electronic items for their livelihood and their heath is at risk; therefore, there is an urgent need to plan a preventive strategy in relation to health hazardous of E-Waste handling among these workers in India. Required information should be provided to these workers regarding safe handling of E-Waste and personal protection. For E-Waste Management many technical solutions are available, but to be adopted in the Management system, prerequisite conditions such as Legislation, Collection System, Logistics, Manpower should be prepared. This may require Operational Research and Evaluation Studies.

\section{Acknowledgment}

Ranjan Singh would like to thank the Department of Higher Education, Government of Uttar Pradesh, Lucknow, Uttar Pradesh, India for the financial help rendered in form of Minor Research Project under the Scheme of "Research and Development in State Universities of Uttar Pradesh" (Letter No. 47/2021/606/77-4-2021-4(56)/2020 Lucknow dated 30-3-2021). Thanks, is also extended to the authorities of Dr. Ram Manohar Lohia Avadh University, Ayodhya, Uttar Pradesh, India, for providing necessary facilities to carry out the work.

\section{References}

Dahl, R. (2002). Who pays for e-junk? Environmental Health Perspective, 110: 196-199.

Baud, I., Grafakos, S., Hordjik, M. and Post, J. (2001). Quality of life and alliances in solid waste management. Cities,18: 312.

Pandve, H. T. (2007). E-Waste management in India: An emerging environmental and health issue. Indian Journal of Environmental Medicine, 11: 116.

Widmer, R., Oswald, H. K., Sinha, D. K., Schnellmann, M. and Heinz, B. (2004). Global perspectives on e-waste. Environmental Impact Assessment Review, 25: 436-458.

Jang, Y. C. and Townsend, T. G. (2003). Leaching of lead from computer printed wire boards and cathode ray tubes by municipal solid waste landfill leachates. Environmental Science Technology, 37: 477-478.

Bathurst, P. A., McMichael, A. J., Wigg, N. R., Vimpani, G. V., Robertson EF et al., (1992). Environmental exposure to Lead and children's intelligence at the age of seven years: The Port Pirie Cohort Study. New England Journal of Medicine, 327: 1279-1284.

Qiu, B., Peng, L., Xu, X., Lin, X., Hong, J. and Huo X. (2004). "Medical Investigation of E-Waste remanufacturing industry in Guiyu Town", In: Proceedings of the International Conference on Electronic Waste and Extended Producer Responsibility, Beijing, China. 79-83. 
Huo, X., Peng, L., Xu, X., Zhang, L., Qiu, B., Qi, Z.et al., (2007). Elevated blood Lead levels of children in Guiyu, An Electronic Waste Recycling Town in China. Environmental Health Perspective, 115: 1113-1117.

Janet, K. Y., Xing, C. G., Xu, Y., Liang, Y., Chen, L.X., Wu, S.C.et al., (2007). Body loadings and health risk assessments of polychlorinated dibenzo-p-dioxines and dibezofurans at an intensive electronic waste recycling site in China. Environmental Science Technology, 41: 7668-7674.

Wang, T., Fu, J. J., Wang, Y., Liao, C., Tao, Y. and Jiang, G. (2009). Use of scalp hair as indicator of human exposure to heavy metals in an electronic waste recycling area. Environmental Pollution,157: 2445-2451.

Leung, A. O., Lutisemburg, W. J., Wong, A. S. and Wong, M.H. (2007). Spatial distribution of polybrominated diphenyl ethers and polychlorinated dibenzo-p-dioxins and bibenzofurans in soil and combined residue at Guiyu: An electronic waste recycling site in southeast China. Environment Science Technology, 41: 2730-2737.

Hicks, C., Dietmar, R. and Eugster, M, (2005). The recycling and disposal of electronic waste in China- legislative and market response. Environmental Impact Assessment Review, 25: 459471.

Roman, L. S. and Puckett, J. (2002). "E-scrap exportation: Challenges and Considerations. In: Proceedings in International Symposium on Electronics and the Environment (IEE)". San Francisco, CA, USA. 7984.

Yanez, L., Ortiz, D., Calderon, J., Batres, L., Carrizales, L., Mejia, J. et al., (2002). Overview of human health and chemical mixtures: Problems facing developing countries. Environment Health Perspective, 110: 901-909.

Kishore, J. (2007). A Dictionary of Public Health. Second Edition. Century Publication, New Delhi, India. 680.

Kishore, J. (2010). National Health Program in India: National Policies and Legislations related to Health. Eighth Edition. Century Publication, New Delhi, India. 735-736.

Environmental management for Informational Technology industry in India. (2003). Department of Information Technology (DIT), Government of India, New Delhi. 122-124.

\section{How to cite this article:}

Mahima Chaurasia, Sanjeev Kumar Srivastava, Ranjan Singh, Ranjana Sikarwar and Rajeeva Gaur. 2021. A Short Review on E-Waste: Challenges and Management in India. Int.J.Curr.Microbiol.App.Sci. 10(05): 20-26. doi: https://doi.org/10.20546/ijcmas.2021.1005.005 